\title{
Pengembangan Model Pembelajaran Matematika Berbasis Pepro Kreasi Di Madrasah Tsanawiyah
}

\begin{abstract}
Mutmainnah*
Abstract: The development of mathematical learning models based on Pepro Kreasi at junior high boarding school. This study aims to develop instructional mathematics models based on Pepro Kreasi (Knowledge, Processes, Creativity, Activity, and Attitude)that can increase the competencies, interest, and student learning outcomes. In edition to using lesson matter book, as well as using assessment instrument.Development of instructional models followed the Dick \& Carey model.this study result the design of instructional, learning resources book that we call Mardhi (mathematics magazine), and the user guide for teacher and student that .Formative test that involved expert testing, one-to-one, small group, and field test, were carried out and resulted in conceptual, procedural, and physical models for the development of viable and effective instructional mathematics models to be used in AlIshlahuddiny junior boarding high school.
\end{abstract}

Keywords: mathematic instructional, models, lesson matter, assessment instrument, and pepro kreasi.

Abstrak: Tujuan penelitian ini menghasilkan model pembelajaran matematika berbasis Pepro Kreasi (Pengetahuan, Proses, Kreativitas, Aplikasi, dan Sikap) yang dapat meningkatkan kompetensi, minat dan hasil belajar siswa. Selain menggunakan bahan ajar, digunakan juga instrumen penilaian dalam kegiatan pembelajaran. Metode yang digunakan dalam Research and Development adalah model pengembangan Dick \& Carey. Hasil penelitian ini adalah desain pembelajaran, bahan ajar yang disebut sebagai Mardhi (majalah Ar-Riyadhiyat), dan buku panduan penggunaan untuk guru dan siswa. Uji coba formatif berupa uji ahli, uji One-to-one, uji kelompok kecil, dan uji lapangan. Penelitian ini menghasilkan model konseptual, prosedural, dan fisikal, yang telah teruji efektivitas, efisiensi dan kelayakannya untuk pembelajaran matematika yang digunakan di madrasah Tsanawiyah Al-Ishlahuddiny.

Kata kunci: pembelajaran matematika, model, bahan ajar, instrumen penilaian, pepro kreasi.

\section{PENDAHULUAN}

Kurikulum tentang belajar matematika menurut Chambers (2008: 88) lebih menekankan untuk memanfaatkan konteks cerita dan kebiasaan siswa, sehingga dalam pembelajaran matematika, penggunaan konteks kehidupan sehari-hari juga dianjurkan untuk diterapkan pada lingkungan belajar siswa.

Matematika yang merupakan bagian dari sains adalah suatu sistem yang kompleks yang terdiri dari banyak domain yang saling berkaitan namun memiliki karakter yang berbeda-beda. Oleh karena itu, tidak ada suatu metode, pendekatan, model ataupun strategi pembelajaran yang paling baik untuk pembelajaran matematika. Suatu pendekatan ataupun metode mungkin hanya bermanfaat untuk pembelajaran suatu konsep tertentu pada level yang tertentu juga.

Selain faktor kurangnya minat siswa dalam

* Mutmainah, Program Studi Teknologi Pendidikan, Jalan Rawamangun Muka Gd.M, Program Pascasarjana, Universitas Negeri Jakarta, Jakarta Timur.muti250281@yahoo.com 
belajar matematika, hasil pembelajaran yang rendah juga dipengaruhi oleh faktor waktu, kurikulum, bahkan juga sumber daya manusia (guru). Siswa pada sebuah madrasah memiliki kegiatan informal di luar sekolah yang cukup padat, diantaranya kegatan diniyah. Semua mata pelajaran dan kegiatan menuntut siswa untuk memperoleh hasil maksimal yang diharapkan guru. Sementara jika ditinjau dari tingkat usia, anak pada tahap perkembangan ini masih membutuhkan waktu bermain dengan teman sebayanya. Sehingga siswa merasa kesulitan dalam mengatur waktu yang tersedia.

Faktor lain yang tidak kalah pentingnya untuk diperhatikan adalah sumber daya manusia, khususnya guru yang langsung terjun dalam dunia pendidikan. Bagaimana profesionalitas guru dalam menyelenggarakan pendidikan dan pembelajaran perlu dikaji. Hal ini mengingat salah satu kemungkinan penyebab kegagalan pendidikan adalah faktor guru sebagai pemegang peran utama dalam penyelenggaraan pendidikan dan pembelajaran di sekolah.

Profesionalitas guru diperkuat oleh data yang dipeoleh dari hasil sharing dengan teman sejawat dilakukan untuk memperoleh model pembelajaran matematika yang sesuai dengan kondisi guru dan siswa. Hasil sharing dengan teman sejawat/guru diperoleh masukan bahwa materi matematika hanya dipahami siswa secara prosedural. Hal ini disebabkan banyaknya rumus yang harus dikuasai oleh siswa. Selain itu dalam pembelajaran di kelas, guru mengalami kesulitan dalam memberikan contoh yang sesuai dengan masalah yang dihadapi siswa dalam kehidupan sehari-harinya. Menurut guru, berdasarkan hasil belajar selama ini yang dapat dilihat dari nilai raport semester sebelumnya, kemampuan belajar matematika siswa berada pada kategori rendah dengan rata-rata nilai klasikal 6 .

Fakta bahwa profesionalisme yang diukur dari kualitas kinerja guru tergambar dari hasil kajian yang dilakukan oleh Kementerian Pendidikan dan Kebudayaan RI tentang uji kompetensi guru. Hasil uji kompetensi terhadap guru yang telah bersertifikat, faktanya ternyata masih di bawah standar kompetensi yang diharapkan. Menurut Gultom (2012) bahwa nilai rata-rata nasional hasil perhitungan uji kompetensi per 1 Juli 2012 adalah 47,84. Berdasarkan hasil studi BERMUTU (2012: 23) dengan skala nilai 5,0 - 95,0, maka hasil uji kompetensi guru tersebut terindikasi masih berada di bawah rata-rata nasional. Hal ini menunjukkan, bahwa angka tersebut masih belum memperlihatkan posisi kualitas penguasaan standar kompetensi guru sebagaimana diharapkan. Padahal, sertifikasi guru sudah berjalan enam tahun saat dilakukan uji kompetensi. Sebagaimana diketahui, berdasarkan Peraturan Pemerintah nomor 19 (2005: 13) bahwa standar yang harus dimiliki guru sebagai agen pembelajaran pada jenjang pendidikan dasar dan menengah serta pendidikan anak usia dini meliputi: a) kompetensi pedagogik; b) kompetensi kepribadian; c) kompetensi profesional; dan d) kompetensi sosial. Dapat diasumsikan, masih rendahnya kualitas standar kompetensi yang dimiliki guru berdampak kepada rendahnya kualitas perencanaan, pelaksanaan, dan pengevaluasian hasil pembelajaran yang dilakukan guru.

Hasil wawancara dengan siswa Madrasah Tsanawiyah Al-Ishlahuddiny Kediri diketahui bahwa model pembelajaran matematika yang ada belum dapat memberikan pengetahuan konseptual secara optimal.Strategi dan metode yang digunakan belum menimbulkan ketertarikan siswa untuk lebih memahami matematika. Pembelajaran matematika hanya berisi materi yang disusun secara monoton untuk tiap kali pertemuan di kelas formal sehingga membosankan bagi siswa. Dengan kata lain bahwa proses belajar mengajar yang diterapkan guru belum mengacu pada standar pembelajaran yang jelas.

Kalau kita bertanya kepada siswa di sekolah tentang mata pelajaran yang paling tidak disukai, 75\% menjawab mata pelajaran matematika. Penjelasan yang diberikan guru hanya dapat di mengerti pada saat penjelasan tersebut diberikan di kelas, tetapi ketika siswa sampai di rumah mereka sudah lupa. Hal ini menunjukkan mereka belum mengerti dengan pengetahuan konseptual. Mereka hanya mengerti pengetahuan prosedural.

Ada $60 \%$ siswa mengatakan bahwa guru mengajar matematika (khususnya di Madrasah Tsanawiyah Al-Ishlahuddiny) umumnya menggunakan metode teacher oriented. Siswa kurang diberi contoh mengenai aplikasi dan manfaat materi, sehingga materi matematika akhirnya hanya diserap siswa secara abstrak. Seharusnya guru mampu menghidupkan suasana belajar, sehingga siswa tidak hanya diam sebagai pendengar saja.

Kekurangmampuan guru dalam meningkatkan minat siswa belajar matematika sebagaimana 
dipaparkan disebabkan oleh beberapa faktor, salah satu diantaranya adalah kurang tersedianya bahan ajar yang dapat dijadikan pedoman. Kalaupun tersedia, bahan ajar tersebut belum disertai dengan contoh nyata dalam pembelajaran sebagaimana dikehendaki para guru, dengan kata lain minimnya ketersediaan bahan ajar yang praktis dan aplikatif sebagaimana dibutuhkan guru. Oleh karena itu, bahan ajar yang tersedia nampaknya belum dapat digunakan secara maksimal.

Upaya peningkatan kualitas pembelajaran harus dilakukan secara komprehensif, tidak hanya ditinjau faktor guru, siswa, bahan ajar, tetapi juga dari kurikulum. Baik buruknya kualitas pendidikan juga dipengaruhi oleh kurikulum. Kurikulum perlu ditinjau agar dapat menyesuaikan dengan kebutuhan masyarakat. Hal ini perlu dilakukan mengingat perkembangan masyarakat yang semakin cepat, sementara tinjauan kurikulum dilakukan tidak secepat perkembangan masyarakat.

Sarana dan prasarana dalam hal ini menjadi penunjang pendidikan yang juga perlu mendapat perhatian. Sarana dan prasarana yang menunjang pendidikan belum dirasakan oleh semua sekolah, khususnya sekolah swasta. Masih banyak sekolah yang mengalami kekurangan sarana dan prasarana untuk memperlancar proses pendidikan dan pembelajaran.

Penelitian yang relevan dengan menerapkan domain dalam sains telah dilakukan oleh Moh. Ali Maghfuri dengan melihat pengaruh model pembelajaran sains dan kemampuan memori siswa terhadap prestasi belajar kimia. Hasil penelitian yang diperoleh dikelompokkan dalam dua ranah, yaitu kognitif dan afektif. Prestasi belajar kimia siswa yang dilihat dari kedua ranah tersebut, menunjukkan bahwa model pembelajaran yang menerapkan domain sains memberikan pengaruh yang signifikan jika dibandingkan dengan pembelajaran konvensional.

Perubahan kurikulum mungkin dapat dibuat secara paralel dengan pembelajaran yang tepat untuk siswa dan guru tentang pengetahuan mengenai sistem penilaian dalam pembelajaran. Kesulitan-kesulitan yang terjadi dalam melaksanakan pembelajaran dan penilaian, perlu dikembangkan sistem pendidikan tepat untuk mengatasi semua karakteristikkarakteristik dan perbedaan individual yang ada pada siswa.

Uraian tentang beberapa faktor yang mempengaruhi rendahnya kualitas pembelajaran semakin lengkap dengan penggunaan metode pembelajaran yang tidak efektif dan efisien pada suatu materi atau pelajaran tertentu. Menurut Yager (2002: 58) bahwa metode pembelajaran yang dilakukan saat ini dalam pembelajaran matematika belum memiliki model pembelajaran yang efektif dan efisien. oleh karena itu lebih lanjut Yager menyatakan bahwa melalui model pembelajaran matematika berbasis "Pepro Kreasi" yaitu pembelajaran dengan menerapkan lima domain dalam sains yang terdiri dari Pengetahuan (knowledge), Proses (processes), Kreativitas (creativity), Aplikasi (application), dan Sikap (attitude), maka sekaligus dapat diterapkan konsep-konsep psikologi perkembangan dan optimalisasi otak kanan (brain theory) yang menghendaki siswa untuk belajar secara kongkret dan mengembangkan kemampuan berpikir divergen (berpikir menyelesaikan masalah dengan banyak alternatif untuk menumbuhkan kreativitas, inovasi, dan imajinasi konstruktif), sehingga siswa diharapkan memiliki pemahaman konsep dasar matematika yang baik agar mampu mengaitkan dengan materi yang akan dibahas selanjutnya.

Orientasi dari perumusan kurikulum 2013 bahwa semua mata pelajaran harus berkontribusi terhadap pembentukan sikap, keterampilan, dan pengetahuan. Perumusan kurikulum tersebut menurut Kunandar (2003: 30) merupakan penyempurnaan pola pikir dari kurikulum KTSP yang memberikan pemisahan antara mata pelajaran pembentuk sikap, pembentuk keterampilan, dan pembentuk pengetahuan. Sedangkan penilaian dalam model pengembangan berbasis Pepro Kreasi lebih luas menilik pada penilaian proses yang dilaksanakan selama pembelajaran berlangsung, dan bagaimana siswa mengembangkan kreativitas dari beberapa konsep yang telah dimiliki.

Pengembangan model pembelajaran matematika berbasis Pepro Kreasi menggunakan kurikulum KTSP, dimana kompetensi lulusan diturunkan dari standar isi, namum lebih luas menerapkan penilaian autentik sesuai dengan perumusan kurikulum 2013, khususnya mata pelajaran matematika berkontribusi bukan saja terhadap pembentukan sikap, keterampilan, dan pengetahuan, tetapi juga terhadap proses, aplikasi, dan kreativitas.

Produk yang dihasilkan berupa bahan ajar yang didesain berbentuk majalah, dan diberi nama Mardhi 
(majalah Ar-Rhiyadhiyat, atau majalah Matematika). Konten dari Mardhi berbeda dengan buku sumber belajar lainnya. Dari segi tampilan, Mardhi di desain sederhana dengan berbagai ilustrasi yang menggambarkan materi. Dari segi bahasa, Mardhi menggunakan bahasa sederhana, familiar, dan tidak kaku, yaitu bahasa yang sering digunakan siswa dalam kehidupan sehari-hari.

Dalam konteks teknologi pembelajaran menurut Miarso (2009: 8), bahwa sumber belajar merupakan segala sesuatu yang dapat digunakan anak didik untuk belajar, baik yang secara khusus dirancang untuk itu maupun yang secara alamiah tersedia di lingkungan setempat untuk dipakai. Sumber ini tidak hanya merupakan sesuatu yang disediakan oleh Departemen Pendidikan dan Kebudayaan saja, apalagi oleh guru kelas saja, melainkan juga sumber yang ada dan dapat digali dari masyarakat. Dengan kata lain, sumber belajar merupakan komponen sistem pembelajaran yang merupakan sumber-sumber belajar yang dirancang terlebih dahulu dalam proses desain atau pemilihan dan pemanfaatan, dan dikombinasikan menjadi sistem pembelajaran yang lengkap untuk mewujudkan terlaksananya proses belajar yang bertujuan dan terkontrol. Teknologi pembelajaran berupaya untuk merancang, mengembangkan, engorganisasikan dan memanfaatkan aneka sumber belajar sehingga dapat memudahkan atau menfasilitasi seseorang untuk belajar.

Artikel ini membahas hasil penelitian pengembangan sebagai upaya untuk meningkatkan hasil belajar siswa dengan pendekatan penilaian Pepro Kreasi Adapun tujuan penelitian ini adalah menghasilkan produk bahan ajar dan instrumen penilaian berbasis Pepro Kreasi bagi siswa kelas VII semester genap, khususnya di madrasah Tsanawiyah Putra Al-Ishlahuddiny.

\section{METODE PENELITIAN}

Joyce dan Weil (2002: 104) mengemukakan bahwa, model pembelajaran adalah suatu rencana atau suatu pola yang digunakan untuk merancang pembelajaran setiap tatap muka di kelas atau dalam tutorial, dan untuk menentukan perangkat pembelajaran termasuk buku, film tape (rekaman), program yang dimediasi komputer dan kurikulum. Setiap model mengarahkan kita untuk mendesain pembelajaran guna membantu siswa sehingga tujuan pembelajaran tercapai. Selanjutnya Joyce dan Weil mengemukakan bahwa model pembelajaran mempunyai unsur: (1) sintaks; (2) sistem sosial; (3) prinsip-prinsip reaksi; (4) sistem pendukung; (5) dampak instruksional; dan (6) dampak pengiring.

Penelitian ini bertujuan untuk mengembangkan sesuatu yang baru dan diharapkan dapat meningkatkan kualitas hasil belajar matematika siswa. Keterampilan yang akan dikembangkan dalam penelitian ini adalah kemampuan untuk menyelesaikan masalah dalam kehidupan sehari-hari yang dituangkan dalam model matematika sehingga hasilnya dapat di presentasikan di depan kelas.

Penelitian ini menggunakan metode penelitian dan pengembangan yang dikolaborasikan dari model pengembangan yang dikemukakan oleh Gall \& Borg (2007:589) dan model pengembangan Dick \& Carey. Diawali dengan penelitian pendahuluan yang pengumpulan datanya dilakukan melalui wawancara, dan angket. Wawancara dilakukan terhadap 5 orang guru, konteks wawancara berhubungan dengan kegiatan pembelajaran di kelas, kemampuan dan minat siswa terhadap pelajaran matematika, dan kelengkapan administrasi guru. Pengisian angket dilakukan oleh 7 orang guru yang mengajar matematika di madrasah Tsanawiyah AlIshlahuddiny.

Berdasarkan analisis kebutuhan dari temuan penelitian pendahuluan, kemudian dikembangkan model pembelajaran matematika berbasis Pepro Kreasi yang ditunjang dengan produk berupa buku pengayaan. Desain pembelajaran dalam pengembangan model ini mengikuti langkah-langkah dalam Model Dick \& Carey. Dalam model Dick \& Carey menurut Suparman (2000: 132) dibagi atas tiga tahapan. Adapun tahapan-tahapan tersebut adalah sebagai berikut: (a) Tahap mengidentifikasi, terdiri dari; 1) mengidentifikasi kebutuhan pembelajaran dan menulis tujuan pembelajaran umum, 2) melakukan analisis pembelajaran, dan 3) mengidentifikasi perilaku dan karakteristik siswa. (b) Tahap mengembangkan, terdiri dari; 1) menulis tujuan pembelajaran khusus, 2) menulis tes acuan patokan, 3) menyusun strategi pembelajaran, dan 4) mengembangkan bahan pembelajaran. (c) Tahap mengevaluasi atau merevisi, yang terdiri dari; 1) Mendesain dan melaksanakan evaluasi formatif yang termasuk didalamnya kegiatan merevisi, 2) merevisi kegiatan pembelajaran, dan 3) mendesain 
dan melaksanakan evaluasi sumatif.

Hasil pengembangan produk dilakukan melalui uji formatif, yaitu: uji ahli, uji one to one, uji kelompok kecil, dan uji lapangan. Selanjutnya, masukan dari hasil uji coba lapangan menjadi dasar terakhir bagi perbaikan dan penyempurnaan produk. Setelah diperbaiki sesuai masukan dari lapangan, maka produk dianggap final dan siapuntuk disebarkan atau digunakan secara massal. Untuk mengetahui keberhasilan implementasi kalau model akan dilaksanakan, maka perlu dilakukan sebuah evaluasi sumatif yaitu setelah pemanfaatan produk berjalan selama periode tertentu, untuk menilai efektif dan efisien suatu produk, untuk menilai apakah produk efektif dan efisien atau tidak. Hal ini berkaitan dengan pengambilan keputusan untuk menentukan apakah pengembangan model tersebut diteruskan atau tidak. Evaluasi pada tahap ini disebut dengan evaluasi sumatif. Tetapi dalam penelitian ini evaluasi sumatif tidak dilakukan disebabkan keterbatasan waktu penelitian.

Penelitian ini dilakukan selamasatu semester, yakni mulai bulan januari 2013 sampai bulan Mei 2013.Untuk mengetahui efektivitas produk dilakukan uji ahli yaitu ahli materi, ahli media pembelajaran, dan ahli desain instruksional, uji one to one kepada 6 orang yang memiliki yang memiliki kemampuan sedang, tinggi, dan rendah, yang dilihat dari nilai raport semester ganjil, uji kelompok kecil kepada 10 orang siswa yang dipilih secara acak, dan uji lapangan kepada 30 orang siswa kelas VII madrasah Tsanawiyah Putra Al-Ishlahuddiny.

\section{HASIL PENELITIAN}

Penelitian yang dilakukan menghasilkan temuan dalam hal kemampuan guru dalam melaksanakan evaluasi pembelajaran matematika di madrasah Tsanawiyah Al-Ishlahuddiny. Guru memiliki pengetahuan yang minim mengenai konsep dasar penilaian hasil belajar. Penilaian hasil belajar peserta didik merupakan sesuatu yang sangat penting dan strategis dalam kegiatan belajar mengajar.

Dengan penilaian hasil belajar maka dapat diketahui seberapa besar keberhasilan peserta didik telah menguasai kompetensi atau materi yang telah diajarkan oleh guru. Melalui penilaian juga dapat dijadikan acuan untuk melihat tingkat keberhasilan atau efektivitas guru dalam pembelajaran. Oleh karena itu, penilaian hasil belajar harus dilakukan dengan baik mulai dari penentuan instrumen, penyusunan instrumen, telaah instrumen, pelaksanaan penilaian, analisis hasil penilaian dan program tindak lanjut hasil penilaian.

Penilaian hasil belajar yang baik akan memberikan informasi yang bermanfaat dalam perbaikan kualitas proses belajar mengajar. Sebaliknya, kalau terjadi kesalahan dalam penilaian hasil belajar, maka akan terjadi salah informasi tentang kualitas proses belajar mengajar dan pada akhirnya tujuan pendidikan yang sesungguhnya tidak akan tercapai.

Kedua, nilai yang diberikan seorang guru kepada peserta didik tidak dapat diperbandingkan dengan nilai yang diperoleh dari guru lainnya. Artinya penilaian yang diberikan oleh guru kepada peserta didik seringkali memiliki perbedaan antara guru yang satu dengan guru yang lainnya.

Ketiga, hasil penilaian yang dilakukan oleh guru terkadang belum sepenuhnya menggambarkan pencapaian kompetensi riil dari peserta didik, sehingga peserta didik yang sudah dinyatakan menguasai kompetensi, misalnya kompetensi dasar (KD) tertentu, ternyata sesungguhnya belum menguasai kompetensi dasar tersebut. Hal ini bisa dilihat dari fakta bahwa ketika peserta didik sudah dikatakan tuntas dari suatu KD dalam ulangan harian (formatif), tetapi ketika diuji lagi untuk KD tersebut dalam Ujian Tengah Semester (UTS) atau ujian lainnya, peserta didik mengalami kesulitan dalam menguasai KD tersebut. Hal ini berarti informasi hasil penilaian oleh guru melalui kegiatan penialain adalah informasi yang kurang valid dan kurang akurat. Dampak dari kurang akuratnya hasil penilaian, maka yang dirugikan adalah peserta didik.

Hasil gabungan penilaian domain proses, sikap, dan kreativitas diperoleh 10 siswa yang mendapat nilai dengan kategori A atau Amat baik, jika dipersentasikan maka terdapat 3,33\% siswa yang mendapat nilai dengan kategori sangat baik. Sedangkan 20 siswa atau sebanyak $66,7 \%$ siswa mendapat nilai dengan kategori baik.

Selanjutnya jika nilai komposit tersebut di sesuaikan dengan penetapan standar nilai Kriteria Ketuntasan Minimal (KKM) yaitu 70, maka semua siswa termasuk dalam kategori tuntas.

Jadi, berdasarkan teori yang telah dipaparkan pada bab III bahwa pembelajaran itu dikatakan berhasil jika memenuhi kriteria ketuntasan sebanyak 
$75 \%$. Dari penilaian kelima domain dalam Pepro Kreasi tersebut (domain pengetahuan dan aplikasi, domain sikap, domain proses, dan domain kreativitas) diperoleh nilai di atas standar, hanya terdapat $10 \%$ dalam domain pengetahuan dan aplikasi yang dinyatakan tidak tuntas.

Hasil pengembangan dari penelitian ini berupa "buku pengayaan untuk Pembelajaran matematika kelas VII semester genap" yang disebut sebagai produk. Sedangkan isi model pembelajaran ini meliputi:

1. Desain model konseptual, dan model prosedural pembelajaran matematika berbasis Pepro Kreasi.

2. Buku pengayaan yang terdiri dari buku 1 sampai buku 3 sesuai dengan Standar Kompetensi (SK) yang ada pada kelas VII semester genap, namun materi yang perkaya adalah materi geometri.
Desain bahan ajar dengan format tampilan penulisan yang tidak baku dan isi sesuai dengan kebutuhan kurikulum sekolah yang ingin diperkaya, di dalamnya disisipi gambar yang mendukung materi yang sedang dibahas dan menggunakan bahasa yang tidak kaku. Desain buku pengayaan dibagi menjadi tiga edisi; (1) edisi pertama, siswa diajak untuk memahami hubungan garis, garis dengan garis, garis dengan sudut, serta menentukan ukurannya, (2) edisi kedua, siswa diajak untuk memaham konsep segiempat yang meliputi sifat-sifatnya, kelilingnya, dan luasnya, dan (3) edisi ketiga, siswa diajak untuk memahami konsep segitiga dan cara melukis garisgaris pada segitiga.

Adapun dalam setiap edisi masing-masing dilengkapi dengan tema; inspirasi yang berisi kisah tokoh-tokoh penting yang memberi inspirasi, simulasi yang berisi aksi seru sebagai pengantar materi yang akan dibahas, konsepsi yang berisi materi matematika yang disajikan dengan konsep

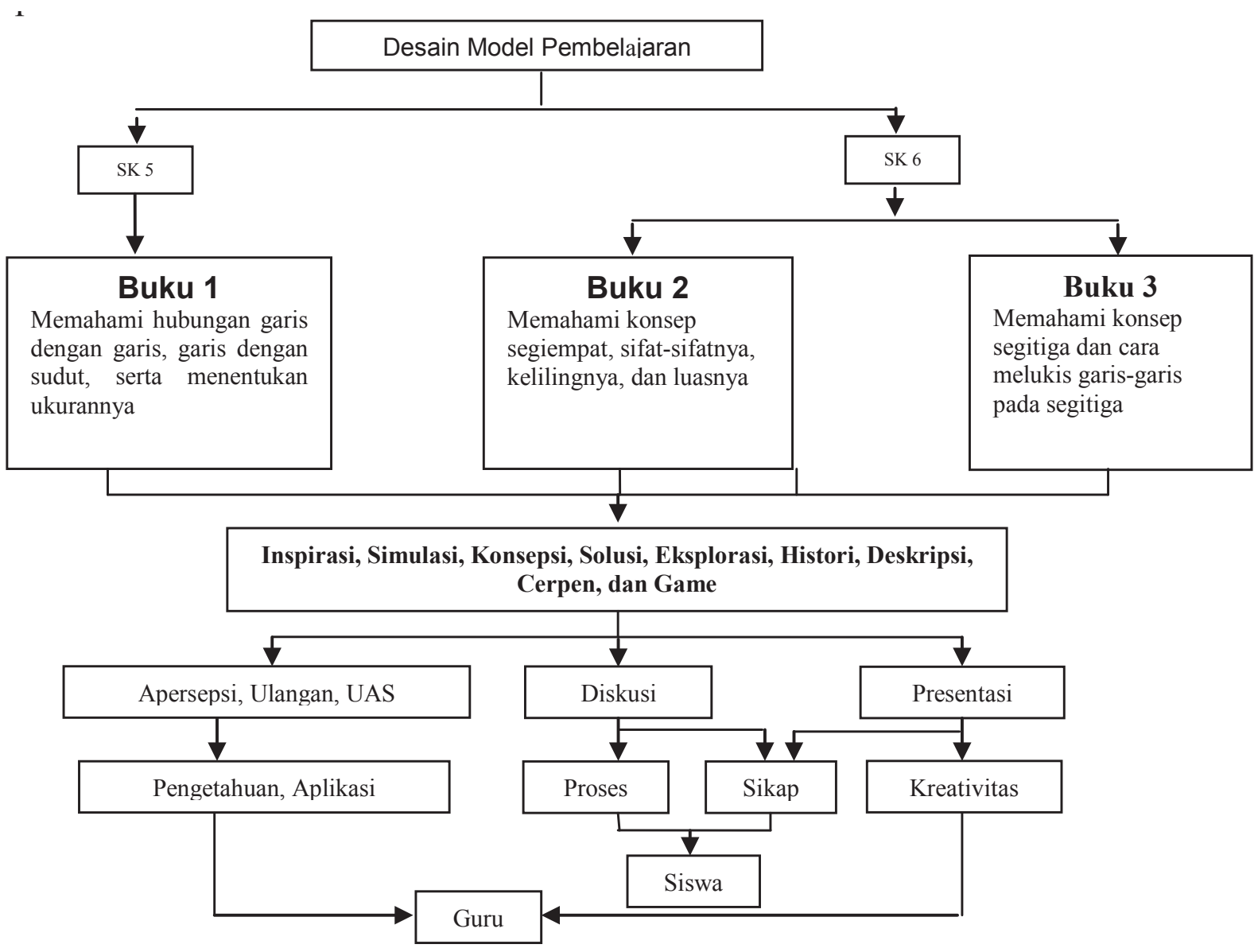

Gambar 1. Desain Model Pembelajaran 
dan gaya bahasa sederhana serta tidak kaku, solusi yang berisi kumpulan permasalahan yang berkaitan dengan materi yang sedang di bahas, eksplorasi yang berisi informasi tambahan yang sayang untuk dilewatkan, histori yang berisi asal-usul atau sejarah yang berkaitan dengan materi, deskripsi yang berisi informasi yang menyuguhkan manfaat yang dapat diperoleh dari materi, cerpen, dan game.

Pengembangan model pembelajaran matematika berbasis Pepro Kreasi, meliputi tiga bentuk, yaitu:

(1) Model konseptual merupakan perwujudan dari konseptualisasi teori-teori dan prinsipprinsip yang terintegrasi sedemikian rupa membentuk bahan ajar matematika berbasis Pepro Kreasi.

(2) Model prosedural merupakan perwujudan tahapan-tahapan pembentukan model pembelajaran matematika berbasis Pepro Kreasi.

(3) Model fisikal adalah hasil nyata berupa desain pembelajaran, 3buku pengayaan, dan pada materi geometri.

Model pembelajaran Matematika berbasis Pepro Kreasi dengan produk buku pengayaan, memiliki beberapa kelebihan dan kelemahan, yaitu:

\section{Kelebihan}

a. Buku pengayaan dibuat dalam ukuran A4 dan bentuk tidak terlalu tebal sehingga memudahkan untuk dibawa

b. Lay-out buku pengayaan pada bagian sampul dibuat dengan angka yang berbeda sehingga memberikan kemudahan bagi pengguna buku pengayaan dalam membedakan antara pokok bahasan satu dengan pokok bahasan yang lainnya.

c. Buku pengayaan dibuat dengan menggunakan bahasa yang sederhana dan setiap edisi memuat inspirasi (kisah tokoh-tokoh penting yang memberi inspirasi), Histori (asal-usul atau sejarah yang berkaitan dengan materi), simulasi (aksi seru sebagai pengantar materi yang akan di bahas), konsepsi (materi matematika yang disajikan dengan konsep dan gaya bahasa sederhana, serta tidak kaku), solusi (kumpulan permasalahan yang berkaitan dengan materi yang sedang dibahas), eksplorasi (informasi tambahan), deskripsi (informasi yang menyuguhkan manfaat yng dapat diperoleh dari materi), cerpen dan game.

d. Materi dalam buku pengayaan menggunakan pendekatan realistik, maksudnya setiap materi dikaitkan dengan contoh benda konkrit yang ada pada lingkungan sekitar atau masalah pada kehidupan sehari-hari.

e. Setiap edisi dalam buku pengayaan dilengkapi dengan tugas mandiri yang harus di paparkan atau di presentasikan di depan kelas.

f. Memberikan motivasi diri peserta didik dalam hal penilaian kegiatan, agar lebih aktif dan berpartisipasi dalam proses pembelajaran.

\section{Kelemahan}

a. Buku pengayaan yang dihasilkan merupakan buku penunjang untuk menambah wawasan peserta didik, jadi masih harus dilengkapi dengan bahan ajar lainnya, karena buku pengayaan ini didesain dengan aturan yang tidak baku yang berisi inspirasi, simulasi, konsepsi, solusi, eksplorasi, histori, deskripsi, cerpen dan game, serta gambar-gambar yang mendukung untuk meningkatkan minat siswa mempelajari materi matematika.

b. Dalam penilaiannya yang berbasis Pepro Kreasi, perlu persiapan yang lengkap, karena terlalu banyak format yang digunakan.

c. Menuntut profesionalisme guru karena mengamati peserta didik yang bervariasi, meskipun dalam penilaian dibantu siswa sebagai penilai, tetapi guru tetap harus memantau dan memverfikasi hasil penilaian siswa.

d. Sulit menyamakan persepsi karena latar belakang yang berbeda.

e. Hasil Penilaian sangat tergantung situasi yang sedang dialami peserta didik sehingga hasilnya berpeluang berbeda.

Pengembangan model pembelajaran matematika berbasis Pepro Kreasiini merupakan upaya dalam memfasilitasi pembelajaran agar tercipta pembelajaran yang efektif, efisien, dan menarik sehingga meningkatkan kompetensi, minat, dan hasil belajar matematika siswa.

\section{PEMBAHASAN}

Penelitian mengenai pengembangan 
model pembelajaran berbasis Pepro Kreasi ini merupakan penelitian yang dilaksanakan dengan menitikberatkan pada penilaian autentik, yaitu kegiatan menilai peserta didik yang menekankan pada apa yang seharusnya dinilai, baik proses maupun hasil dengan berbagai instrumen penilaian yang disesuaikan dengan tuntutan kompetensi yang ada di Standar Kompetensi (SK) dan Kompetensi Dasar (KD). Penilain yang dilakukan dalam model ini adalah penilaian untuk mendapatkan nilai pengetahuan, proses, kreativitas, aplikasi, dan sikap peserta didik. Baik sikap dalam kehidupan sehari-hari maupun sikap terhadap pembelajaran matematika. Pelaksanaan penilaian tidak hanya dilimpahkan pada guru, tetapi dengan melibatkan peserta didik. Peserta didik diberikan penjelasan tentang aspek-aspek penilaian yang sudah dipaparkan guru dalam lembar penilaian. Hasil penilaian siswa selanjutnya diverifikasi oleh guru, karena siswa belum bisa sepenuhnya menilai temannya secara objektif. Pelaksanaan penilaian tersebut disesuaikan dengan perkembangan karakteristik peserta didik sesuai dengan jenjangnya.

Penelitian yang dilakukan menghasilkan temuan dalam hal kemampuan guru dalam melaksanakan evaluasi pembelajaran matematika di madrasah Tsanawiyah Al-Ishlahuddiny. Model pembelajaran ini dapat diterapkan sesuai dengan kurikulum nasional 2013, karena terdapat domain penilaian yang tidak jauh beda dengan standar penilaian yang ada pada kurikulum 2013.

Berdasarkan temuan penelitian maka pembahasan hasil penelitian ini akan dijabarkan di bawah ini:

Desain pengembangan model dalam pembelajaran matematika berbasis Pepro Kreasi mengacu pada dua desain, yaitu desain model pembelajaran, yang didalamnya berisi desain penilain Pepro Kreasi dan desain buku pengayaan. Desain penilaian dalam model pembelajaran Pepro Kreasi diantaranya; (1) penilaian domain pengetahuan dan aplikasi, diperoleh dari nilai ulangan harian, ulangan tengah semester (UTS) dan ulangan akhir semester (UAS), (2) penilaian domain sikap, diperoleh dari nilai diskusi dan presentasi dengan format penilaian teman sejawat, (3) penilaian domain proses, diperoleh dari proses penyelesaian masalah matematika yang berupa tahap persiapan, tahap pelaksanaan, dan tahap hasil pengamatan, dengan format penilaian teman sejawat, dan(4) penilaian domain kreativitas, yang diperoleh dari pemberian tugas mandiri yang dipresentasikan di depan kelas, penilaian domain ini diberikan oleh guru.

Berdasarkan kemampuan pedagogi guru matematika secara umum, maka dilakukan analisis kebutuhan di lapangan yaitu perlu di kembangkan suatu model pembelajaran dengan serangkaian kegiatan yang sesuai disertai dengan bahan ajar yang dapat digunakan oleh guru dan siswa dalam melaksanakan pembelajaran secara lebih baik lagi. Agar model pembelajaran ini dapat diterapkan sesuai dengan karakteristik siswa yang lebih memahami masalah berdasarkan apa yang ditemukan dalam kehidupan seharihari. Pendekatan yang dipilih dan peneliti anggap sesuai dengan kondisi, kebutuhan dan karakteristik siswa adalah pendekatan realistik.

Jadi, proses belajar matematika harus ditekankan pada konsep yang dikenal siswa. Setiap siswa mempunyai seperangkat pengetahuan yang telah dimilikinya sebagai akibat dari interaksi dengan lingkungan atau proses belajar sebelumnya. Setelah siswa terlibat dalam proses belajar yang bermakna, siswa mengembangkan lebih lanjut pengetahuan tersebut ke tingkat yang lebih tinggi. Dalam proses tersebut, siswa secara aktif memperoleh pengetahuan baru. Pembentukan pengetahuan adalah proses perubahan yang bergerak secara perlahan dari tingkat pertama ke tingkat kedua, kemudian ke tingkat ketiga. Dalam proses tersebut siswa bertanggung jawab terhadap aktivitas belajar yang dilaksanakannya.

Implementasi pembelajaran berbasis Pepro Kreasi dan dianalisis terhadap nilai ulangan siswa untuk setiap edisi (standar kompetensi), maka diperoleh nilai siswa yang berpatokan pada nilai diatas kriteria ketuntasan minimal (KKM). Nilai sikap, nilai proses, dan nilai kreativitas dikalkulasi untuk masing-masing siswa dan digabungkan menjadi sebuah nilai komposit untuk mendapatkan kategori untuk tiap domain. Maka dapat ditarik kesimpulan bahwa bahan ajar tersebut adalah layak dan efektif untuk diimplementasikan di sekitar lingkungan madrasah Tsanawiyah Al-Ishlahuddiny untuk 
kalangan terbatas.

Pencapaian kompetensi peserta didik tidak hanya dibandingkan dengan kompetensi peserta didik lainnya, tetapi dibandingkan juga dengan standar kriteria ketuntasan minimal (KKM), yang ditetapkan berdasarkan; (1) tingkat kompleksitas materi, (2) kemampuan sumber daya pendukung dalam penyelenggaraan pembelajaran, dan (3) tingkat kemampuan (intake) rata-rata peserta didik di sekolah yang bersangkutan.

Penelitian ini memiliki keterbatasan, yaitu: Dalam pelaksanaannya, mulai dari proses penelitian pendahuluan, pengembangan produk, dan evaluasi formatif disadari sepenuhnya masih dtemukan keterbatasan-keterbatasan yang menjadi catatan, baik oleh peneliti maupun peneliti berikutnya. Hal pertama yang menjadi catatan sebagai keterbatasan hasil pengembangan ini adalah, bahwa bahan ajar yang dihasilkan masih bersifat sebagai pelengkap yang di desain untuk meningkatkan minat belajar siswa dan menambah wawasan keilmuwan. Jadi guru harus tetap membutuhkan bahan ajar lain.

Dalam kegiatan pembelajaran menggunakan penilaian Pepro Kreasi, maka dituntut profesionalisme guru dalam melakukan pengamatan dan penilaian agar diperoleh berbagai data yang dapat memberikan gambaran perkembangan belajar siswa.

Ditinjau dari sisi dukungan teori model yang digunakan, bahwa model pengembangan ini menggunakan model Dick \& Carey. Dari sepuluh langkah pengembangan yang ada, penelitian pengembangan ini hanya sampai pada langkah kedelapan, yakni evaluasi formatif.

Pengembangan model pembelajaran harus disesuaikan dengan perkembangan kurikulum yang digunakan, sedangkan kurikulum yang digunakan selalu berubah sesuai dengan perkembangan zaman. Sehingga diperlukan model pembelajaran terbaru dan upgrading secara terus-menerus untuk menyelaraskan dengan perkembangan tersebut.

\section{KESIMPULAN}

Kesimpulan dalam penelitian ini adalah: pertama, strategi penggunaan pendekatan realistik yang berdampak langsung pada domain Pepro Kreasi adalah dengan memberikan contoh soal konkrit yang dekat dengan kehidupan sehari-hari siswa. Kedua, tahapan untuk merancang dan implementasi perangkat pembelajaran matematika agar dapat digunakan dalam model pembelajaran matematika berbasis Pepro Kreasi adalah dengan melakukan evaluasi formatif secara bertahap. Ketiga, Desain model pembelajaran matematika berbasis Pepro Kreasi terbukti dapat meningkatkan penguasaan kompetensi siswa, yang bukan hanya kompetensi kognitif (yang di dalamnya terdapat ranah pengetahuan dan sikap) saja, tapi lebih jauh meningkatkan kompetensi afektif (di dalamnya terdapat ranah aplikasi) dan psikomotorik (di dalamnya terdapat ranah keterampilan). Sehingga dapat disimpulkan bahwa pengembangan model pembelajaran matematika berbasis Pepro Kreasi dapat meningkatkan kompetensi, minat dan hasil belajar matematika siswa.

Pengembangan model pembelajaran matematika berupa bahan ajar berbasis Pepro Kreasi memberikan dampak dalam peningkatan kompetensi siswa dan kemampuan guru yang sebelumnya tidak berkembang secara optimal. Selain itu hasil temuan juga berdampak pada guru agar mempersiapkan kurikulum 2013 dengan mempersiapkan sumber belajar yang relevan dengan kebutuhan di lapangan, perlu kerjasama antar antar pihak dalam mendesain dan melaksanakan pembelajaran bagi peningkatan kompetensi siswa. Implikasi positif juga diberikan bagi guru dalam menerapkan kurikulum 2013 yang berbasis penilaian autentik. Oleh sebab itu, penting untuk dijadikan perhatian oleh pemerintah daerah tentang adanya kebijakan bahwa buku sumber belajar yang telah dikembangkan ini dapat dipergunakan di sekolah.

Pertama, pendekatan realistik yang digunakan dalam model pembelajaran Pepro Kreasi terbukti memudahkan dan membantu siswa memahami materi yang diberikan, karena materi diberikan dengan didekatkan pada kehidupan sehari-hari siswa. Hal ini disebabkan bahwa sebenarnya siswa sudah memiliki pengetahuan dan pengalaman yang berbeda satu dengan lainnya, selain itu jenjang pendidikan yang mengharuskan model dan pendekatan pembelajaran yang sesuai dengan tingkat kemampuan dan perkembangan peserta didik. Sehingga dengan pendekatan ini pelaksanaan proses pembelajaran menjadi lebih menarik karena di desain dengan kegiatan pembelajaran yang menuntut siswa aktif dan kreatif. Belajar menjadi manusia yang tidak hanya bisa dinilai 
orang lain, tetapi juga mampu menilai orang lain, sehingga dituntut menjadi sosok yang objektif. Tidak melihat kepada "siapa" yang memberikan jawaban, tetapi jawaban "apa" yang mampu diberikan.

Kedua, langkah-langkah Dick \& Carey yang digunakan dalam pengembangan bahan ajar berbasis Pepro Kreasi ini telah memberikan sumbangan pemikiran terhadap pengembangan desain model pembelajaran dan proses pengembangan bahan ajar yang digunakan dalam kegiatan pembelajaran di kelas. Untuk merancang dan mengembangkan sebuah buku sumber belajar berbasis Pepro Kreasi sangat diperlukan bagi peningkatan kemampuan siswa dan guru dalam melaksanakan kegiatan belajar mengajar. Sehingga bahan ajar yang sudah melalui berbagai proses uji dan revisi, dapat mempermudah dan menjadi acuan dalam melaksanakan pembelajaran.

Ketiga, implikasi positif terhadap dampak uji coba buku pengayaan berbasis Pepro Kreasi ini tidak hanya terlihat dari minat dan motivasi, tetapi juga tergambar dari peningkatan hasil belajar siswa yang sudah dilakukan subjek uji coba. Jika sebelum menggunakan buku pengayaan berbasis Pepro Kreasi guru hanya terbatas pada RPP dan metode pembelajaran yang bersifat monoton, maka setelah penggunaan buku pengayaan guru bisa memberikan pembelajaran kepada siswa dengan menggunakan metode aktif dan kreatif sehingga tidak menjadi pembelajaran yang membosankan. Metode pembelajaran dikelas tidak terpaku pada ceramah, namun diterapkan model diskusi agar proses pembelajaran menjadi lebih interaktif, kelas diskusi juga terlihat lebih variatif. Implikasi bagi siswa secara keseluruhan yaitu pembelajaran menjadi lebih menarik, munculnya berbagai kreativitas dan perubahan perilaku siswa khususnya dalam pembelajaran matematika menjadi lebih baik.

\section{DAFTAR RUJUKAN}

Chambers, P. Teaching Mathematics: Developing as a Reflective Secondary Teacher. (Thousand Oaks : Corwin Press : 2008).h.88

Gultom, Syawal. "Hasil Uji Kompetensi Guru Masih di Bawah Harapan", www.tempo.co/ read/news/2012/08/03/079421057/Hasil-UjiKompetensi-Guru-Masih-di-Bawah-Harapan (diakses, 3 Juli 2014)
Gall, Damien M., dan Walter R. Borg. Educational Research: An Introduction. New York: Longman, Inc.

Joyce, B. And Weil, M. Models of Teaching. (New Jersey: Prantice Hall, 2002).

Kementerian Pendidikan Nasional, Laporan Hasil Studi BERMUTU 2010 Dampak DBL KKG/ MGMP (Jakarta, Badan Penelitian dan Pengembangan Pusat Penilaian Pendidikan, 2010).

Kunandar, Dr. Penilaian Autentik. Suatu Pendekatan Praktis (Jakarta: Raja Grafindo Persada, 2013)

Miarso, Yusufhadi. Menyemai Benih Teknologi Pendidikan. Jakarta: Kencana 2008.

Peraturan Pemerintah Nomor 19 Tahun 2005 Tentang Standar Nasional Pendidikan, Pasal 28, Ayat 3.

Suparman,Atwi. Desain Instruksional. Jakarta: Universitas Terbuka, 2010.

Yager, R.E. Science/Technology/Society as reform in science education. (New York: State University of New York,2 